\title{
PEMAHAMAN HADIS KEPEMIMPINAN QURAISY (Studi Komparatif Tipologi Kepemimpinan Quraisy Dengan Tipologi Kepemimpinan Di Indonesia)
}

\author{
Mila Melyani ${ }^{1}$ \\ Reza Pahlevi Dalimounthe ${ }^{2}$ \\ Universitas Islam Negeri Sunan Gunung Djati Bandung \\ 1. A.H. Nasution No.105, Cipadung, Kec. Cibiru, Kota Bandung, Jawa Barat 40614 \\ ${ }^{1}$ melyanimila29@gmail.com² rezapdhalimunthe@ uinsgd.ac.id
}

\begin{abstract}
:
Many people consider that the Quraish leadership hadith is no longer relevant today, because Islam has spread throughout the world. Then what about Indonesia because Indonesia is a Republican country. As a country with the most Muslim majority in the matter of appointing a leader, it is certainly a problem in itself. This study focuses on the meaning of the Quraish leadership tradition which can be universally understood and can also be contextualized for Indonesia by studying the typology of Quraish leadership and Indonesian leadership typology using comparative methodology. If applied from the hadith of the Quraish leadership into the context of Indonesia, the most important criterion that a leader must have in Indonesia is that of a generous, honest, trustworthy and fair nature.
\end{abstract}

Keywords: hadith, leadership; typology Quraish; typology Indonesia

\begin{abstract}
Banyak orang menilai bahwa hadis kepemimpinan Quraisy itu sudah tidak relevan lagi di masa sekarang, karena Islam telah menyebar diseluruh dunia. Lalu bagaimanakah dengan Indonesia karena negara Indonesia ialah negara yang berbentuk Republik. Sebagai negara yang mayoritas Muslim terbanyak dalam soal pengangkatan pemimpin tentu menjadi masalah tersendiri. Penelitian ini memfokuskan kepada bagaimana makna hadis Kepempinan Quraisy yang bisa difahami secara universal dan juga bisa dikontekstualisasikan untuk Indonesia dengan mengkaji tipologi kepemimpinan Quraisy dan tipologi kepemimpinan Indonesia dengan menggunakan metodologi komparatif. Apabila diaplikasikan dari hadis kepemimpinan Quraisy kedalam konteks ke Indonesiaan, maka kriteria yang terpenting yang harus dimiliki seorang memimpin di Indonesia ialah yang memiliki sifat murah hati, jujur, amanah dan adil.
\end{abstract}

Kata kunci: Hadis; Kepemimpinan; Tipologi Quraisy;Tipologi Indonesia.

\section{A. PENDAhULUAN}

Islam sangat memperhatikan keberadaan kepemimpinan dalam segala aspek, meskipun terhadap perkara yang sederhana, ${ }^{1}$ seperti halnya dalam hadis Nabi yang berbunyi:

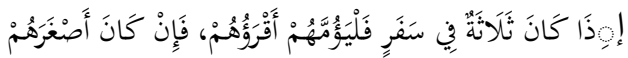

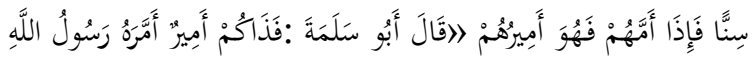

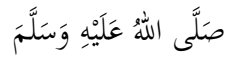

"jika kalian terdiri dari tiga orang maka angkatlah salah satu nya menjadi pemimpin."

${ }^{1}$ Yusuf Qardawi, terj. Wahab Aziz, Konsep Islam Solusi Utama Bagi Umat, ( Jakarta: Senayan Abadi Publising, 2004), 165.
Hal ini menunjukan simbol konsistensi koordinasi terhadap kelompok yang lebih besar dari rombongan orang yang bepergian tersebut, dengan demikian rombongan tersebut hanya terdiri dari tiga orang diantara mereka harus dijadikan pemimpin. Disebutkan dalam sebuah hadis yang terdapat dalam kitab shahih nya Al-Bukhāri mengenai kepemimpinan Quraisy ialah:

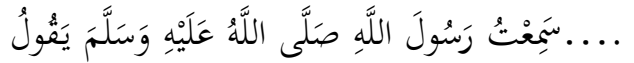

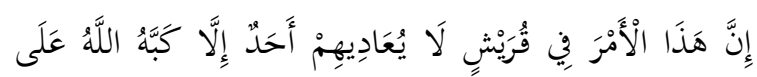

$$
\begin{aligned}
& \text { وَجْهِهِ مَا أََََامُوا الدَّينَ.. } \\
& \text { Sungguh aku pernah mendengar } \\
& \text { Rasulullah Shallallhu 'alaihi wa salam }
\end{aligned}
$$


bersabda: "Sesungguhnya urusan (khilāfah/ pemerintahan) ini berada pada suku Quraisy dan tidak ada seorangpun yang menentang mereka melainkan Allah Ta'ala pasti akan menelungkupkan wajahnya ke tanah selama mereka (Quraisy) menegakkan al-din (agama)" 3

Hadis tersebut merupakan hadis yang shahih, apabila difahami sesuai teks hadis tersebut disebutkan kepemimpinan itu harus dari kaum Quraisy, akan tetapi jika hadis itu dipahami dengan cara tekstual nya saja, tanpa mempertimbangkan kontesktualnya pasti akan menimbulkan permasalahan, karena Islam telah menyebar diseluruh dunia. Lalu bagaimanakah dengan Indonesia karena negara Indonesia ialah negara yang berbentuk Republik kekuasaan dan pemerintahan yang dipegang oleh presiden, sebagai negara yang mayoritas Muslim terbanyak dalam soal pengangkatan pemimpin tentu menjadi masalah tersendiri bagi penduduk Indonesia yang salah satu nya ialah apabila pengangkatan pemimpin di Indonesia harus sesuai dengan hadis kepemimpinan Quraisy, pasti akan sulit jika diterapkan sesuai arti literalnya.

Menurut Ibnu Khaldun bahwa syarat kepemimpinan Quraisy bukanlah "harga mati" yang harus dilaksanakan dalam sepanjang masa. Menurutnya Rasulullah SAW. menjelaskan persyaratan suku Quraisy untuk menjadi kepala megara ialah dikarenakan pada masa itu suku Quraisy mempunyai wibawa serta kekuatan yang disegani di Jazirah Arab karena suku Quraisy memiliki 'așabiyyah atau solidaritas kelompok yang kuat. Ikatan solidaritas inilah yang membuat mereka menjadi pemimpin yang kuat pada masa itu. Menurut Ibnu Khaldūn hadis syarat Quraisy merupakan pemahaman simbolik karena suku Quraisy sebagai simboli pada saat itu hanya suku Quraisy yang memiliki kuatnya solidaritas. Namun seiring berjalannya waktu perkembangan serta perubahan

\footnotetext{
${ }^{3}$ Abu Abdullah Muhammad Ibn Isma'il al Bukhari, Shahih al Bukhari Juz IV( t.tp: Dar Mutabi syabi, t.,t), 217-218.

4 Mila Melyani, Pemahaman Hadith

Kepemimpinan Quraish Studi Komparasi
}

situasi dan kondisi tidak menutup untuk suku yang lain yang lebih kuat sehingga jika suku Quraisy dalam keadaan tidak lagi suku yang menjadi suku yang paling kuat dan berwibawa maka kepemimpinannya itu dapat berpindah ke suku-suku yang lain yang memiliki kekuatan dan kewibawaan besar serta fanatisme yang lebih kuat. Sebagai mana dalam kitab Muqaddimah nya Ibnu Khaldūn mengatakan” Imam itu berasal dari suku Quraisy, atau suku lain yang memiliki kemampuan dan kecakapan sebagaimana yang dimiliki suku Quraisy" 4

Inti yang utama dari hadis kepemimpinan Quraisy ialah pada substansinya, bukan pada makna literalnya, maksud dari nabi Muhammad SAW. dalam pengangkatan pemimpin bukan hanya berdasarkan pada keturunan semata, akan tetapi kepada siapapun yang memiliki pengaruh kuat dan berwibawa, ketika diterapkan di Indonesia yang berhak menjadi pemimpin ialah yang sesuai dengan kriteria yang dimunculkan oleh kata Quraisy dalam hadis mengenai kepemimpinan Quraisy. Dengan demikian, pemaknaan hadis kepemimpinan Quraisy bisa diartikan dengan memilih pemimpin dengan makna simbolik, yang berarti simbol kepemimpinan seperti suku Quraisy yang memiliki wibawa, cerdas, memiliki solidaritas yang tinggi dan memiliki dukungan yang kuat (dominan).

\section{B. PEMBAHASAN}

\section{a. Pengertian Tipologi}

Tipologi berdasarkan ciri-ciri tertentu sebagai kriteria menetapkan tipetipe bagaimana kepemimpinan pada kedua negara tersebut.

Tipologi adalah ilmu mengenai tipe. Tipe ialah pola sifat individu, kelompok dan lain sebagainya. Tipe digunakan karena mereka menyajikan sarana klasifikasi dari pribadi-pribadi atau kelompok-kelompok yang berguna untuk tujuan analisis. Suatu

\footnotetext{
Ibnu Taimiyyah dan Ibnu Khaldun," (Skripsi Program Sarjana Universitas Islam Negari Sunan Gunung Djati Bandung: 2019), 125.
} 
tipe ideal ialah gagasan mental yang terbentuk dari susunan unsur-unsur karakteristik sejumlah fenomena yang digunakan dalam analisis. Unsur tersebut diabstraksikan didasarkan pada pengamatan terhadap situasisituasi yang kongkret dari fenomena yang dipelajari, namun gagasan yang dihasilkan tidak perlu harus berkaitan persis dengan pengamatan empiris. Tipe yang ideal merupakan teknik metodologis yang penting, dapat digunakan untuk melukis, membandingkan dan menguji hipotesis yang berhubungan dengan kenyataan empiris. Tipe-tipe yang tersusun demikian ini terbentuk dari kriteria (unsur, ciri, aspek, dan lainlain) yang memiliki refersensi yang dapat ditemukan dalam dunia empiris atau dapat disimpulkan secara sah dari evidasi empiris. Tipe yang tersusun ini bukan saja menyediakan cara untuk pengaturan data, namun berguna untuk membantu generalisasi. ${ }^{5}$

Banyak tokoh yang telah melakukan pengkajian yang mendalam mengenai prilaku kepemimpinan dengan berbagai pendekatan dan objek kajian. Faktanya dari berbagai kajian tersebut munculah pernakpernik teori kepemimpinan yang menghiasi perkembangan kajian akademik. Pemimpin itu memiliki sifat, kebiasaan, watak serta kepribadianya sendiri yang khas sehingga tingkah laku serta gaya yang membedakan dirinya dengan yang lain. Gaya hidupnya pasti akan mewarnai perilaku serta tipe kepemimpinannya, sehingga munculah beberapa tipe kepemimpinan, contohnya ialah tipe karismatis, paternalistis, militeris, otokratis, laissez fire, populis, administratis dan demokratis. Menurut pengamatan setiap pemimpin memiliki kecenderungan utuk memperguanakan jenis kepemimpinan tertentu, cenderung dapat dlihat dengan jelas pada saat ia mempergunakan jenis kepemimpinan yang tepat pada situasi tertentu.

5 Mariasuasai Dhavamony, Fenomenology Agama, Kanisius, (Yogyakarta;1995), 29.

${ }^{6}$ Martin Lings, Muhammad,Terj.

Qomaruddin SF, Kisah Hidup Nabi Berdasarkan Sumber Klasik, (Jakarta: PT Serambi Ilmu Merdeka, 2007), 16.

${ }^{7}$ Lings, Kisah Hidup Nabi Berdasarkan Sumber Klasik, 16.

\section{b Tipologi kepemimpinan Quraisy}

Kata Quraisy yang dimaksud ialah suatu suku dari bangsa Arab merupakan keturunan Nabi Ibrahim yang paling kuat. ${ }^{6}$ mereka diduga berasal dari keturunan Bani Ismail melalui anaknya ialah Adna dan ada yang menyebut dengan nama Arab Adnam dan Quraisy termasuk satu cabang, mereka ialah anak dari Fihir Ibn Malik Ibn Nadar Ibn Kinanah. Quraisy terpecah belah menjadi kabilah yang banyak diantaranya ialah; Saham, Jamah, Adi, Ta'im dan dari keturunan Qushai Ibn Kilab. Seorang lelaki dari suku Quraisy yang bernama Qushai menikahi anak perempuan Hulayl Ibn Habsyah pemimpin Khuzaah, kaum Kuzaah ialah suku Arab keturunan Ismail yang berimigrasi dari yaman ke Mekkah. ${ }^{7}$

Kemudian pada masa kelahiran Rasulullah SAW. penduduk kota Mekkah terdiri dari berbagai suku bangsa.pada saat itu yang paling berkuasa dan terkenal ialah dengan sebutan Quraisy, ${ }^{8}$ suku ini terbagi menjadi empat, pertama Quraisy dalam ialah yang terdiri dari kelompok bisnis aristokratis, pedagang-pedagang, wirausaha, bankir-bankir. Kedua Quraisy Luar yaitu sejumlah penduduk yang lebih kecil terdiri dari pedagang-pedagang, pemukiman yang statusnya lebih rendah dan lebih muda. Kemudian ketiga ada juga sekelompok proletar yang terdiri dari suku badui dan orang asing. Keempat Diluar kota Makkah Ada Quraisy Arab yang hidupnya tergantung pada situasi pemerintahan kota Mekkah sebagai Republik kota Saudagar, menurut sejarah mereka dikatakan suku yang paling kuat serta dominan, terkenal dan berwibawa dibandingkan suku Mudhar lainnya. Mereka juga paling disegani di Jazirah Arab pada zaman dahulum masyarakat Arab sangat tunduk kepada mereka. ${ }^{9}$

\footnotetext{
${ }^{8}$ Bernard Lewis, Terj. Said Jamhuri, Bangsa Arab dalam Lintasan Sejarah, 17-18.

${ }^{9}$ Abdul Karim Munte, DKK, Meluruskan Pemahaman Hadis Kaum Jihadis,(Tanggerang Selatan: Yayasan Pengkaji Hadis el-Bukhori, 2017), 94-95.
} 
Qushai memerintah di Mekkah seperti seorang raja dengan kekuasaan yang tidak tertandingi, masyarakat Mekkah selalu membayarnya setiap tahun dengan domba, sehingga beliau dapat menyediakan makanan untuk jamaah Haji yang tak mampu. Sebelumnya para penjaga ka'bah tinggal ditenda-tenda selasar Ka'bah, namun Qushai menyuruh mereka membangun rumah dan kemudian membangun sebuah kediaman yang luas untuknya yang dikenal dengan Rumah Majlis. ${ }^{10}$ Dalam waktu yang singkat berkembang menjadi masyarakat perdagangan yang penting, kewajiban masyarakat Mekkah untuk membayar upeti kepada Qushai secara tidak langsung menggambarkan bagaimana aliansi Qushai sebagai suku Quraisy dengan klan-klan yang lain, secara otomatis memberikan kekuatan politik terhada suku Quraisy, hal tersebut menjadikan suku Quraisy memiliki derajat yang lebih tinggi dibandingkan suku yang lain. Fakta yang lain ialah suku Quraisy pemegang kunci Ka'bah dan air, segala kegiatan keagamaan di Ka'bah terkendali dibawah pemerintahan Quraisy. Dan air ialah sumber kehidupan pun berada pada kendali suku Quraisy, karena suku Quraisy dapat memberikan perlindungan dan mempu melerai konflik perpecahan. Bisa dikatakan kehidupan Mekkah tergantung kepda keputusan Quraisy, suku Quraisy juga mempnyai sikap yang amanah serta solidaritas uang tinggi ${ }^{11}$

Dengan demikian kepemimpinan suku Quraisy memiliki dua tipologi, yakni:

\section{Keluhuran tata sosial}

Seorang pemimpin dibutuhkan spesifikasi yang harus dimiliki agar kepemimpinan berjalan sebagaimana mestinya yaitu seorang pemimpin harus memiliki kapasitas kecerdasan, kewaspadaan, kemampuan untuk bercakap dan kemampuan untuk menilai dan menimbang melebihi anggotanya, harus bertanggung jawab, mandiri dan memiliki sosiabilitas yang tingi, tekun serta percaya diri. Suku Quraisy memiliki aṣabiyyah yang kuat, oleh karena itu seorang pemimpin harus memiliki solidaritas kelompok yang besar. Dengan demikian tumbuhnya ashabiyyah karena keturunan, ikatan hubungan yang dekat, persekutuan hubungan bertetangga yang harmonis serta hubungan antara pelindung dan yang dilindungi menimbulkan cinta kasih kerjasama dalam menghadapi suka dan duka bersama-sama, rasa cinta setiap orang terhadap nasabnya serta golongannya yang diciptakan oleh Allah SWT

\section{Berpengaruh}

Dengan adanya solidaritas yang kuat ( keluhuran tata sosial) Perekonomian suku Quraisy yang mapan serta kekuatan politik yang sangat kuat dan rakyat yang banyak sehingga mampu memberikan pengaruh serta perlindungan, melerai konflik perpecahan, mengendalikan ketertiban negara dan melindunginya, dari ancaman baik dari dalam ataupun dari luar, harus mempunyai wibawa yang besar serta kekuatan fisik yang memadai. Dengan demikian seorang pemimpin memerlukan solidaritas kelompok yang kuat dan besar dengan loyalitas dari kelompoknya dalam menghadapi tantangan dan ancaman baik itu dari dalam ataupun dari luar negri terhadap otoritas dan kekuasaannya. Maka dari itu dari berbagai kelompok yang berada di negara tersebut, kepala negara harus berasal dari solidaritas kelompok yang paling banyak.

\section{Berwibawa}

Dikarenakan suku Quraisy terkenal dengan sikap yang amanah, berwibawa serta memiiki solidaritas yang sangat kuat, hal tersebut penting sekali bagi seorang pemimpin. Konsep persyaratan kepemimpinan itu selalu dikaitkan dengan tiga hal terpenting yakni, kekuasaan, kewibawaan serta kemampuan.

\section{c. Tipologi kepemimpinan Indonesia}

Tipe kepemimpinan di indonesia dapat digolongkan menjadi 5 golongan yakni:
${ }^{10}$ Lings, Kisah Hidup Nabi Berdasarkan Sumber Klasik, 17.
${ }^{11}$ Lings, Kisah Hidup Nabi Berdasarkan Sumber Klasik, 21. 


\section{Tipologi Pemersatu}

Dalam bukunya feith The Decline of Constitutional Democracy in Indonesia (1962), disebutkan bahwa Presiden saat itu ialah Soekarno merupakan tipologi pemimpinan pemersatu. Pemimpin dengan menggunakan tipe pemersatu biasanya mampu mengumpulkan dukungan rakyat sehingga dapat mempengaruhi rakyatnya, namun ketika harus mengelola pemerintahan, dia gagal serta dapat mengecewakan.

\section{Tipologi Pengelola}

Sedangkan wakil presiden Muhammad Hatta yang merupakan tipologi kepemimpinan bersifat pengelola, Kedua karakter kepemimpinan ini sangat langka dimiliki dalam diri satu orang. Sebaliknya para pemimpin dengan tipe pengelola umumnya mampu mengelola pemerintahan namun kurang mendapat dukungan dari rakyatnya. Dikarenakan kurang menguasai retorika dan tak memiliki kecakapan yang cukup untuk mendekati massa, tipe pemimpin pengelola biasanya sering disalahfahami oleh orang. Dengan demikian tentu saja tipe ideal ialah apabila kedua karakter ini bersatu dalam satu tokoh.

\section{Tipologi Transformatif Transaksional}

Menurut Liddle, jenis kepemimpinan transformasional yang mengubah Indonesia dari satu fase yaitu penjajahan ke fase lain yaitu kemerdekaan. Akan tetapi menurut Liddle, Soekarno hanya terjadi sejak awal kemerdekaan sampai tahun 1949. Kemudian setelahnya Soekarno menjadi pemimpin yang memiliki visi transformatif. Setelah pemilu pada tahun 1955-1965, kepemimpinan berada pada Sukarno. Dengan kemampuan Soekarno sebagai otorator yang handal, ia mampu mendapatkan dukungan dari rakyat selain kemampuan Soekarno untuk meredamkan disintegrasi bangsa yang mulai mengancam kedaulatan Indonesia pada saat itu. Namun, Soekarno kurang berhasil dalam mengelola pemerintahan pada masa itu, apalagi terjadinya "friksi" antara Soekarno dan Hatta. Kemampuan Hatta dalam mengelola mulai ditinggalkan Soekarno yang tampak mulai melenggang menjadi peemimpin tunggal setelah mengadopsi demokrasi terpimpin.

Liddle berpendapat bahwa Habibie ialah seperti lilin kebijakan-kebijakannya memberikan jalan bagi demokrasi dan kebebasan di Indonesia namun kebijakankebijakannya itu membuat Habibie tidak terpilih lagi dalam pemilu pada tahun 1999. Berbagai kebijakan yang dihasilkan misalnya memberikan kesempatan bagi rakyat Timor Timur melakukan referendum apakah memilih begabung dengan Indonesia atau berdiri sendiri menjadi negara sendiri. Akhirnya, Timor Timur lepas dari negara Indonesia yang berdasarkan hasil referendum tersebut. Selain itu, kebijakan Habibie yang transformative juga tampak ketika tuntutan diadakannya pemilihan umum.bahkan pemilu pada masa Habibie dikatakan pemilu demokratis kedua setelah pemilu 1995 dengan mengadopsi system multi partai. ${ }^{12}$

\section{Tipologi Kharismatik Transformasional}

Pada pemilu tahun 1999 memunculkan pemimpin yang baru di Indonesia yaitu Abdurrahman Wahid dan Megawati Soekarno Putri sebagai preseiden dan wakil presiden. Berdasarkan beberapa fakta dan data pada kecenderungan pola komunikasi serta dominasi tindakan yang pernah dilakukan Gus Dur pada saat menjabat dalam struktur politik cenderung mengarah pada pola komunikasi kharismatik yang dimiliki oleh seorang ulama atau kiayi yang merupakan sosok yang paling penting dalam perkembangan suatu organisasi NU, kegamaan terbesar di Indonesia karena Gus Dur dari keluarga dua tokoh besar yakni KH. Hasyim Asyari dan KH. Bisri Syansuri yang merupakan pendiri organisasi tersebut sehingga pola komunikasi yang dibangun mengarah pada pola komunikasi kharismatikseperti komunikasi antara kiayi dan

12 Muhammad, Gunawan(ed), Calon Presiden Kita, Jakarta: Majalah Indonesia,2014 
santri, hal inilah yang menyebabkan Gus Dur ketika menjabat sebagai pemimpin cenderung berkomunikasi dengan bentuk komunikasi kharismatik yang dimilikinya. Kharismatik yang dimiliki Gus Dur dimanfaatkan sebagai upaya memotivasi bawahannya dengan membuat mereka menyadari pentingnya tugas yang akan dicapai. Gus Dur dan Megawati merupakan tokoh pada masa kepemimpinan Suharto mendapatkan pembatasan ruang gerak. Sebagai tokoh agama yang merupakan keturunan pendiri Nahdatul Ulama, Gus Dur selalu dianggap ancaman bagi kepemimpinan Soeharto, begitupula dengan Megawati yang merupakan putri dari presiden pertama RI, beliau mendapatkan perlakuan diskriminatif pada masa Orde Baru berkuasa. Perlakuan tidak adil yang sering dialami oleh Megawati, contohnya saat pemilihan umm partai Demokrasi Indonesia (PDI). Kepemimpinan zaman Soeharto mampu memunculkan kekuatan tandingan dalam tubuh PDI hingga munculah Surjadi sebagai ketua umum yang terpilih, untuk menghalangi naiknya Megawati sebagai kandidat ketua (PDI).

Tipe kepemimpinan Gusdur ialah tipe Kharismatik Transformasional, Pengertian tipe kharismatik ialah tipe kepemimpinan yang merujuk pada kepribadian seseorang yang memiliki daya tarik dalam berpenampilan dan berkomunikasi, seorang yang berkharisma mempunyai daya pikat yang sangat luar biasa, pemimpin semacam ini sangat percaya diri, tegas, menonjol dalam banyak hal, otentik, fokus dan mempunyai keahlian berpidato yang membuat audiensinya seakan-akan tersihir oleh mantranya.

Sedangkan tipe transformasional ialah tipe pemimpin yang mencoba mengubah dan memotivasi para pengikut dengan membuat mereka menyadari pentingnya tugas mereka dan membujuk mereka ,mendahulukan kepentingan tim dan organisasi dari pda kehidupan pribadi.Hal ini berdasarkan pada perubahan yang diimplementasikan Gus Dur dalam bentuk kebijakan politik sehingga mendeskripsikan tipe kepemimpinan pola transformasional yang berdasarkan kebijakan yang visioner seperti pembubaran Departemen Penerangan dan Departemen sosial, membuka hubungan dagang dengan Israel, pemisahan TNIPOLRI, seringnya melakukan reshuflle kabinet, mengeluarkan Dekrit Presiden, melakukan kunjungan ke luar negri.

\section{Tipologi Transaksional}

Roda kekuasaa pun bergulir kepada Susilo Bambang Yudhoyono yang terpilih dengan pemilihan umum pada tahun 2004 serta pemilihan umum presiden dan wakil presiden secara langsung pada tahun 2009. Tampaknya kepemimpinan belum berubah secara signifikan, Tipologi kepemimpinan Susilo masih kental dengan transaksional maupun dengan wakil-wakilnya yakni Jusuf Kalla dan Boediono. Jusuf Kalla barangkali dinilai memiliki sedikit prestasi terutama dalam mengubah pola pengambilan keputusan yang relatif cepat serta transformatif

Dengan demikian, tampaknya selama ini kepemimpinan di Indonesia masih didominasi oleh kepemimpinan tipe administrator dan transaksional, sangat jarang terjadi kepemimpinan yang mampu menunjukkan sikap pemersatu dan trasformatif. Hal ini berlaku di hampir semua level pemerintahan dan birokrasi baik dari level pusat maupun daerah, bahkan hingga dalam tubuh partai politik.

Persamaan dan perbedaan tipologi kepemimpinan Indonesia dan Kepemimpinan Quraisy

a. Persamaan Tipologi Kepemimpinan di Indonesia dan Kepemimpinan Quraisy

1. Di negara Indonesia memiliki tipologi kepemimpinan pemersatu yang artinya biasanya mampu mengumpulkan dukungan rakyat sehingga dapat mempengaruhi rakyatnya, hal ini sama dengan tipologi kepemimpinan suku Quraisy yang bersifat ashabiyah.

2. Jika Tipologi pemimpin di Indonesia bersifat kharismatik yang dianut oleh salah satu yang pernah menjabat sebagai presiden yakni Gus Dur, maka di Quraisy memiliki Kharismatik pula yang berbentuk kewibawaan. 
3. Kepemimpinan suku Quraisy pada saat itu ialah pemimpin yang berpengaruh dengan tata sosial yang luhur paling ditakuti dan paling kuat, baik dari segi kuat berperang maupun kuat dalam dukungan rakyatnya. hal ini berbeda dengan tipologi kepemimpinan di Indonesia, yang menjadi syarat pemimpin tidak hanya kuat secara militer namun mampu memberikan perubahan kepada Indonesia untuk lebih maju dalam pengelolaan negara.

Quraisy

Tipologi hadis kepemimpinan

$$
\begin{aligned}
& \text { حدثنا عبد الله حدثني أبي حدثنا محمد بن جعفر }
\end{aligned}
$$

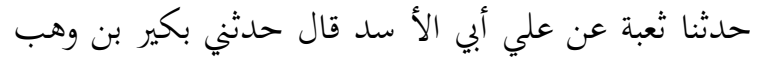

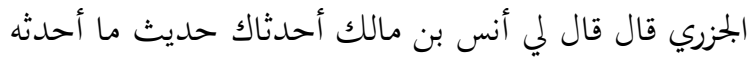

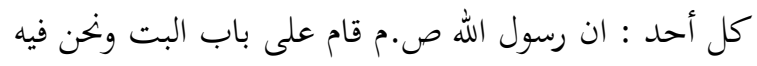

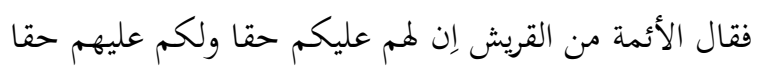

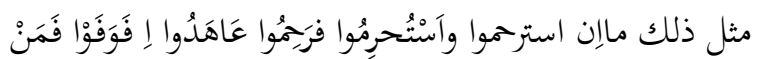

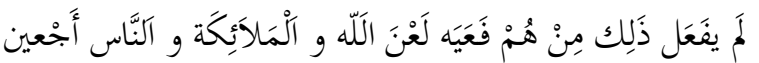

"Abdullāh menceritakan, mencerita-

kan kepadaku ayahku, Muhammad bin Ja'far bercerita Syu'bah dari 'A berkata: Menceritakan kepadaku Bukair bin Wahab al-Jazari ia berkata: berkata kepadaku Anas bin Malik, aku akan menceritakan kepadamu cerita yang dibicarakan oleh setiap orang, yaitu sesungguhnya Rasulullah saw. berdiri di muka pintu, sedangkan kami berada disitu, dan ia bersabda: "Kepemimpinan itu ada di tangan Quraish" sesungguhnya mereka mempunyai hak atas kalian dan kalian pun mempunyai hak atas mereka. Apabila mereka diminta untuk berbelas kasih, mereka akan memberikan belas kasih, apabila mereka berjanji, mereka menepati janji, dan apabila mereka menghakimi, mereka berlaku adil. Barang siapa di antara mereka tidak melaksanakan hal tersebut diatas, maka laknat Allah, malaikat, dan seluruh manusia atas mereka." 13

Dari hadis diatas dapat disimpulkan menjadi tiga bagian yakni;

13 Ibnu Hanbal, Musnād Imām Ahmad bin Hanbal, 129.
1. Simpati, murah hati

وآستُحرِمُوا فريمَمُا yang artinya berbelas kasih atau mengasihi, dapat diartikan dengan bentuk kemurahan hati, simpati seorang pemimpin terhadap rakyatnya, hal tersebut sangat penting untuk kriteria seorang pemimpin, walaupun pasti akan sulit menjumpai pemimpin yang berwatak murah hati. Rasulullah SAW. memberikan contoh kepada umatnya, jadilah seperti pemimpin yang memiliki sifat seperti pemimpin Quraisy.

\section{Sifat Jujur dan Amanah}

Jujur, tulus atau bisa juga disebut shidiq. Kejujuran dan ketulusan adalah kunci utama untuk membangun sebuah kepercayaan. Dapat dibayangkan jika pemimpin sebuah organisasi, masyarakat atau Negara, tidak mempuyai kejujuran tentu orang-orang yang dipimpin tidak akan punya kepercayaan, jika demikian yang terjadi adalah krisis kepercayaan. Dari hadis kepemimpinan Quraish diatas terdapat lafaz عَاََدُوا yang berarti berjanji, apabila rakyat telah mempercayai seorang pemimimpin yang berjanji, maka permimpin tersebut harus bersikap jujur dengan cara ditepati janji tersebut seperti halnya dikatakan Rasulullah bahwa kaum Quraish selalu menepati janji nya

\section{Adil}

Adil yang dimaksudkan dari hadis ini Kata \َوََفَوْا yang berarti memenuhi, memenuhi hak kepada rakyatnya dengan tidak pandang ras suku dan berlaku secara adil dan apabila menetapkan hukuman maka seorang pemimpin harus berlaku adil pula.

Dalam riwayat hadis diatas, nampak jelas sekali keharusan patuh dan taat kepada kepemimpinan suku Qurasaish, dalam arti selama mereka menegakan agama, dengan sifat pemimpin yang bersifat adil jujur dan amanah, selama pemimpinya masih dalam jalan Allah maka sebagai rakyat memiliki kewajiban untuk taat. 


\section{KESIMPULAN}

Dengan demikian makna Quraisy menjadi tiga kriteria yakni keluhuran tata sosial, berpengaruh dan berwibawa, apabila diaplikasikan dalam konteks ke Indonesiaan, maka kriteria paling penting yang harus dimiliki oleh calon pemimpin Nusantara berdasarkan hadis kepemimpnan Quraisy ialah :

Pemimpin di Indonesia harus memiliki sikap yang amanah dalam memegang janji, amanah terhadap tugas yang dipikul serta memiliki jiwa solidaritas yan kuat terhadap masyarakat, karena pemimpin adalah seorang yang diberi amanah untuk mencapai kemaslahatan bersama dunia dan ahirat.

Dan bersikap adil dalam memutuskan perkara tidak pandang bulu, dan hukuman itu tidak dapat ditukar dengan nominal jumlah uang yang dapat diperjual belikan.

\section{DAFTAR PUSTAKA}

Al-Bukhari, Abu Abdullah Muhammad Ibn Isma'il Shahih al Bukhari Juz IVt.tp: Dar Mutabi syabi, t.t.

Al-Shan'ani, Abdul Razaq. Mushanaf Abdul Razaq Al-Shan'ani, no 3812 jilid II.

Lewis, Bernard Terj. Said Jamhuri, Bangsa Arab dalam Lintasan Sejarah, Dhavamony, Mariasuasai. Fenomenology Agama, Kanisius, Yogyakarta;1995.

Martin Lings, Muhammad. Terj. Qomaruddin SF, Kisah Hidup Nabi Berdasarkan Sumber Klasik, Jakarta: PT Serambi Ilmu Merdeka, 2007.

Muhammad, Gunawan (ed), Calon Presiden Kita, Jakarta: Majalah Indonesia, 2014.

Munte, Abdul Karim DKK, Meluruskan Pemahaman Hadis Kaum Jihadis, Tanggerang Selatan: Yayasan Pengkaji Hadis el-Bukhori, 2017.

Yusuf Qardawi, terj. Wahab Aziz, Konsep Islam Solusi Utama Bagi Umat, Jakarta: Senayan Abadi Publising, 2004. 